\title{
Communication
}

[Comunicação]

\section{First report of paratuberculose in Southern Pudu deer (Artyodactila: Cervidae)}

\author{
[Primeiro caso de paratuberculose em veado pudu-do-sul
} (Artiodactila: Cervidae)]

\section{González-Acuña, V. Neira-Ramirez, L. Moreno-Salas, M. Quezada}

Universidad de Concepción, Facultad de Ciencias Veterinarias Avenida Vicente Méndez 595, Chillán, Chile

Paratuberculosis, also called Johne's disease, is caused by the acid-fast bacillus bacteria Mycobacterium avium subspecies paratuberculosis (MAP) (Clarke, 1997). MAP has a long incubation period in the animal and is highly resistant in the environment. It is commonly found in domestic ruminants, particularly in cattle, where it produces substantial economic losses (Ayele et al., 2002). The disease's most obvious manifestation is a progressive thinning of infected animal's stools, causing intense diarrhoea, usually resulting in death. Pathologically, MAP infection causes an intense proliferative enteritis linfogranulomatous in the region of the ileum, which has been described in different domestic ruminants and wildlife around the world (Machacova et al., 2004; Kruze et al., 2006). In Chile, the infection has been reported in cattle (Grinbergs and Caorsi, 1958), sheep (Zamora et al., 1975) and domestic goats (Kruze et al., 2006). However, despite the wide range of possible hosts, paratuberculosis has not been officially diagnosed in wild species. This report is to describe a case of paratuberculosis disease in Southern Pudu, Pudu pudu, endemic to the southern region of South America.

In July 2005, a Southern Pudu carcass was found in a kennel southeast of Concepción, Bío-Bío, Chile $\left(36^{\circ} 53 ' 2.31\right.$ "S , $73^{\circ} 3^{\prime} 59.85$ "W). The carcass was sent to the Department of Veterinary Pathology, University of Concepción, where it was examined postmortem. Specimens were obtained from lungs, heart, liver, kidneys, spleen, small intestine, large intestine and ileocecal lymph nodes for histopathology. The samples were fixed, dehydrated and embedded in paraffin. Sections of $4 \mu \mathrm{m}$ were routinely stained with hematoxylin and eosin following standard procedures for mycobacteria. The samples were also stained with Ziehl-Neelsen (ZN) acid fast stain, a technique adopted by the Organization World Animal Health for the diagnosis of paratuberculosis OIE (Manual..., 2008).

The animal was found in poor condition and with clear signs of diarrhea (i.e., the perineal area was dirty). Internally, the Pudu had no subcutaneous fat reserves or peritoneum and showed serious atrophy of fat in the heart, indicating a state of advanced emaciation. The ileum was thickened, and the adjacent ileocecal lymph nodes were enlarged. Histopathologically, the lungs showed congestion, alveolar and interstitial edema. The liver presented general congestion, some intralobular multifocal inflammation with the presence of macrophages and foamy cytoplasm, and hemosiderin pigment. The spleen was congestive with hemosiderosis. The kidneys showed congestion and the presence of tubulonefrosis basophils stones. The mucosa of the ileum was thickened and intensely infiltrated by macrophages with ample cytoplasm with vacuoles, and with them Langhans giant cells were also observed. Similarly, the ilio-cecal lymph nodes and lymphoid tissues were barely recognizable, because they were heavily infiltrated by activated macrophages and Langhans giant cells (Figure 1). ZN staining of the ileum (Figure 2) and mesenteric lymph nodes were found to be strongly positive for acid-

Recebido em 21 de maio de 2010

Aceito em 13 de abril de 2011

E-mail: danigonz@udec.cl 
resistant bacteria. The lesions observed in the intestinal mucosa and ileocecal lymph node are pathognomonic for paratuberculosis in cattle according OIE, which may well be extrapolated to other ruminants, as in this case in Pudu.
Histological lesions are evidence that the large intestinal damage caused constant diarrhoea in the animal, leading to death due to lack of nutrients.

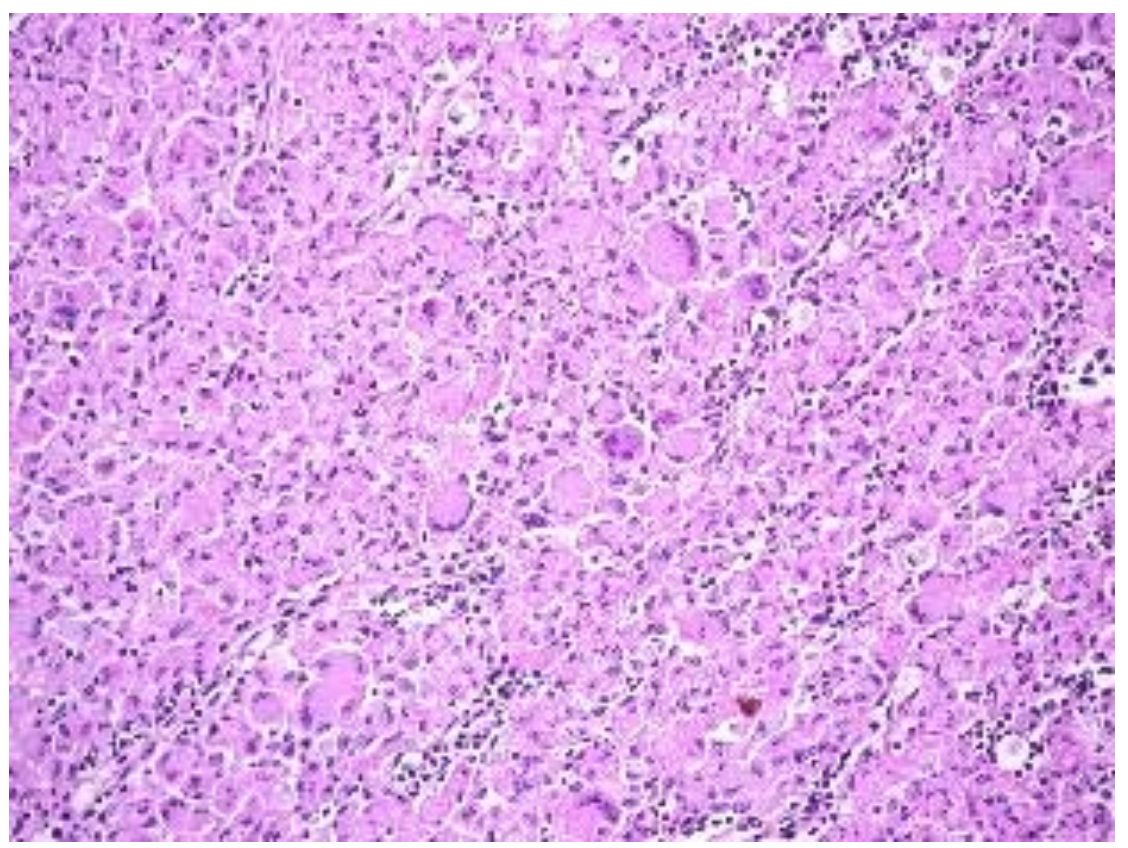

Figure 1. Pudu-do-sul. Ileocecal lymph node, infiltration of activated macrophages and Langhans giant cells in medulla and cortex zone. H-E x100.

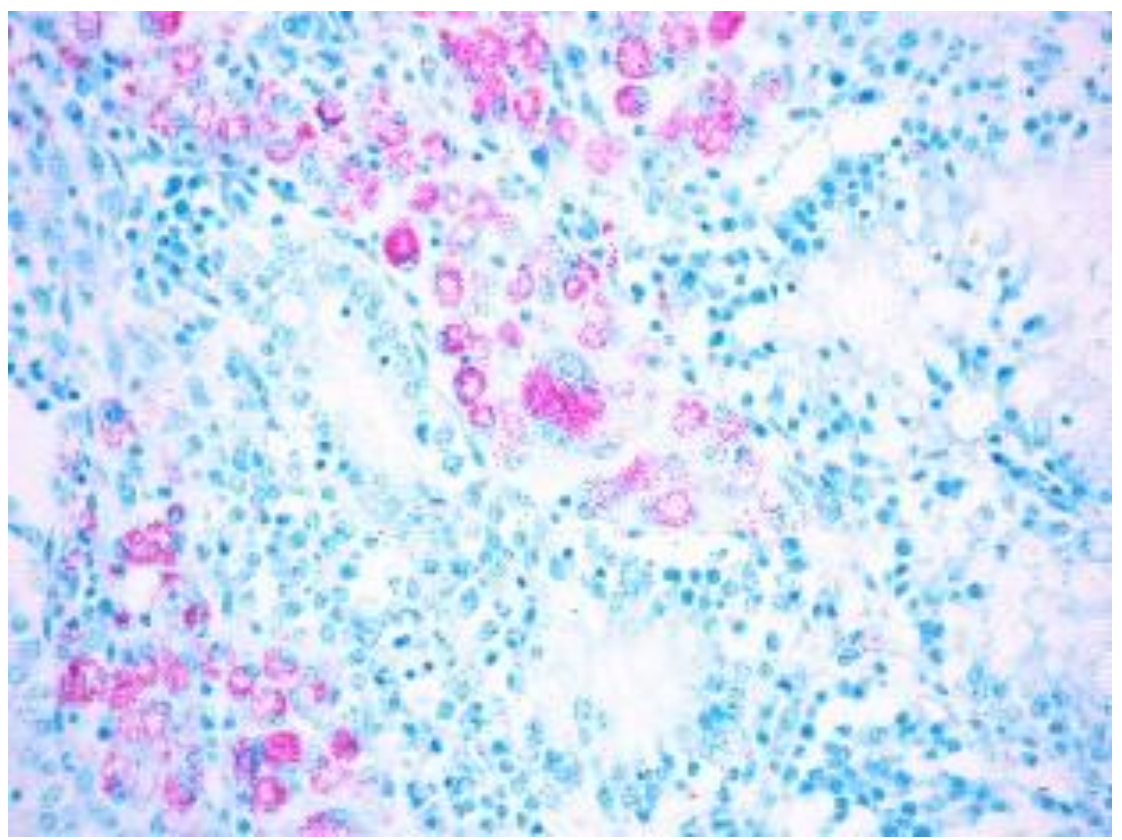

Figure 2. Pudu-do-sul. Ileum, the mucosal glands surrounded by macrophages and giant cells highly loaded with acid-fast bacteria. Z-N 100x. 
This report demonstrates the susceptibility of Pudu for the first time against MAP and indicates a picture very similar to that produced by MAP in domestic ruminants (Coelho et al., 2008). Moreover, this was recently diagnosed in captive South American camelids in Argentina, which makes one suspect that confinement could be important for the presentation of the disease (Jorge et al., 2008). To confirm the importance of this disease in wildlife and in particular to the Pudu, the first priority is to collect data on the prevalence and routes of the infection in the wild, especially for those species found in critical condition conservation.

Keywords: southern Pudu, paratuberculosis, wildlife, Chile

\section{RESUMO}

Descreve-se o primeiro caso de paratuberculose em veado pudu-do-sul (Pudu pudu). O animal foi encontrado na cidade de Concepción, centro sul do Chile, em péssimas condições e com sinais claros de diarréia. Internamente apresentava séria atrofia de gordura no coração, lesões histológicas nos pulmões, fígado, baço e rins, e injúrias intestinais. Diferentes amostras foram preparadas com Ziehl-Neelsen, e os linfonodos mesentéricos presentes no íleo foram fortemente positivos para a bactéria resistente ao ácido.

Palavras-chave: veado, paratuberculose, vida selvagem, Chile

\section{ACKNOWLEDGMENTS}

We thank Darci Batesti for the abstract in Portuguese.

\section{REFERENCES}

AYELE, W.Y.; FISCHER, O.; SVASTOVA, P. et al. Dairy and beef cattle paratuberculosis survey in intensive and beef cattle paratuberculosis survey in intensive and extensive farming conditions. In: INTERNATIONAL COLLOQUIUM ON PARATUBERCULOSIS, 7., 2002, Bilbao, Spain. Proceedings... Kennett Square: International Association for Paratuberculoses, 2002. p.340-344.

CLARKE, C.J. The pathology and pathogenesis of paratuberculosis in ruminants and other species. J. Comp. Path., v.116, p.217-261, 1997.

COELHO, A.C.; PINTO, M.L.; COELHO, A.M. et al. Coloração de Ziehl-Neelsen como método rápido de diagnóstico de paratuberculose ovina. Arq. Bras. Med. Vet. Zootec., v.60, p.1097-1102, 2008.

GRINBERGS, J.; CAORSI, I. Enfermedad de Johne o paratuberculosis en Chile. Publ. Cient. Universidad Austral de Chile, v.4, p.9-13, 1958.
JORGE, M.C.; TRAVERSA, M.J.; SCHETTINO, D.M. et al. Lama glama con signología y lesiones compatibles con paratuberculosis causadas por Mycobacterium avium subespecie avium. In Vet. v.10, p.59-64, 2008. Disponível em: <http://www.scielo.org.ar/scielo.php?script=sci_ arttext\&pid=S1668-34982008000100007\&lng=es>. Acessado em: 23 abr. 2010.

KRUZE, J.; SALGADO, M.; PAREDES, E. et $a l$. Goat paratuberculosis in Chile: first isolations and confirmation of Mycobacterium avium subespecies paratuberculosis infection in a dairy goat. J. Vet. Res., v.17, p.549-551, 2006.

MACHACKOVA, M.; SVASTOVA, P.; LAMKA, J. et al. Paratuberculosis in farmed and free-living wild ruminants in the Czech republic in the years 1999-2001. Vet. Micobiol., v.101, p.225-234, 2004.

OIE. Manual de las pruebas de diagnóstico y de las vacunas para los animales terrestres. 4.ed., Paris, 2008.

ZAMORA, J.; KRUZE, J.; SCHIFFERLI, C. Paratuberculosis ovina. Primer caso descrito en Chile. Arch. Med. Vet., v.7, p.15-17, 1975. 